\title{
POSSIBILITIES OF REGULATING ANTIOXIDANT ACTIVITY OF MEDICINAL PLANT EXTRACTS
}

\author{
I.U. Potoroko', irina_potoroko@mail.ru, ORCID: 0000-0002-3059-8061, \\ I.V. Kalinina ${ }^{1}$, ORCID: 0000-0002-6242-9870, \\ N.V. Naumenko ${ }^{1}$, ORCID: 0000-0002-9520-3251, \\ R.I. Fatkullin ${ }^{1}$, ORCID: 0000-0002-1498-0703, \\ S. Shaik2, shabana89.chem@gmail.com, ORCID: 0000-0001-7133-5754, \\ S.H. Sonawane2, shirish@nitw.ac.in, ORCID: 0000-0002-3201-6731, \\ D. Ivanova ${ }^{3}$, dg_ivanova@yahoo.com, ORCID: 0000-0002-8336-2925, \\ Y. Kiselova-Kaneva ${ }^{3}$, ykisselova@abv.bg, ORCID: 0000-0001-9692-6227, \\ O. Tolstykh ${ }^{1}$, tolga@bk.ru, ORCID: 0000-0002-3112-7026, \\ A.V. Paymulina ${ }^{1}$, paimulinaav@susu.ru, ORCID: 0000-0003-4981-717X \\ ${ }^{1}$ South Ural State University, Chelyabinsk, Russian Federation, \\ ${ }^{2}$ National Institute of Technology, Warangal, India, \\ ${ }^{3}$ Medical University of Varna named after Dr. Paraskev Stoyanov, Varna, Bulgaria
}

The aim of the paper. The aim of the present paper is to evaluate the effectiveness of extracting biologically active substances of antioxidant action from plant raw materials on the basis of applying different extraction approaches. Materials and methods. We did the chemical research of BAS extracts Lonicera caerulea L. and Urtica folia L. concerning their migration parameters during fraction division (honeysuckle berries) and changing extraction conditions (dried nettle leaves). Freeze-drying of raw material (by means of a freeze-drying apparatus "Ineye-6" under the following conditions: temperature $-50 \pm 5{ }^{\circ} \mathrm{C}$, pressure no more than $6 \mathrm{~Pa}$ ) was applied to preserve the bioactivity in a honeysuckle fraction. The experiment included a wide range of chemical parameters - antioxidant activity (AOA), mass fraction of extractives, phenol compounds, anthocyanins and vitamins. The UFLC Shimadzu Corporation Pump: LC-20AD Detector: SPD-M20A Prominence Diode array detector was used to identify bioactive substances. Results and discussion. The paper studies the influence of various approaches concerning bioactive compounds extraction from Lonicera caerulea L. and Urtica folia L. The application of ultrasound (US) with frequencies $22 \pm 0.6 \mathrm{kHz}$ increases the effectiveness of extraction process. It helps to conduct extraction at low temperatures $\left(60 \pm 2{ }^{\circ} \mathrm{C}\right)$ without using chemical reagents. The paper presents the results of water and ethanol extraction obtained from different fractions of honeysuckle and dried nettle leaves. It also provides the results of antioxidant activity analysis of this extraction and a total of antioxidant activity. Urtica folia L extracted by US of $120 \mathrm{~W}$ $(2,4043 \pm 0,084 \mathrm{mg} / \mathrm{ml})$ and a sample based on the water-ethanol extraction agent without an ultrasonic bath $(2,5209 \pm 0,032 \mathrm{mg} / \mathrm{ml})$ showed higher antioxidant activity. We defined the technological parameters of obtaining a dry extract of Lonicera caerulea $L$ by means of ultrasound and freeze-drying for preserving the maximum bioactive compounds of raw material (up to 92-85\%). Conclusion. The results of the experiment proved that ultrasound-assisted extraction improves the extraction kinetics and the output of bioactive compounds from the substrate. The extraction technology excludes the infusion stage which reduces energy intensity.

Keywords: medicinal plants, extraction, biologically active compounds, antioxidant activity, ultrasound.

\section{Introduction}

The development of effective technologies for the extraction of biologically active substances (BAS) from plant raw materials is currently one of the priority areas for the development of organic food ingredients market. The popularity of this segment of products is growing significantly in pharmaceutical, food and processing industries. Among the properties of BAS, isolated from medicinal plants, a special place is given to the study of antioxidant activity (AOA) of their extracts, since it is assumed that high AOA makes a significant contribution to their therapeutic effect $[2,5,6]$. Antioxidants block the oxidation process by neutralizing free radicals, but they themselves begin to undergo 


\section{Спортивное питание}

oxidation processes, and therefore there is a need to replenish the oxidative resources of the human body [8].

Numerous studies of Russian and foreign scientists have shown that AOA extracts are associated with the presence of polyphenols $[17,21]$. Biological effects of plant polyphenols are realized by means of nonspecific interaction with different targets from proteins to low molecular substances and their ions [13]. Polyphenols are capable of direct inhibition of free radicals $[23,33]$ and chelation of metals, including iron $[1,18]$. Researchers have studied in detail antioxidant properties of flavonoids which contribute to the wide range of their biological effects [15]. It is proved that flavonoids are able to activate natural mechanisms of cell defense against oxidative stress through the expression of intracellular enzymes. Numerous experimental studies have established the antioxidant effect of more than 50 isolated flavonoids [23, 24]. However, low bioavailability of most flavonoid compounds makes it difficult to use them in pure form [13, 44].

One of the most popular antioxidants is ascorbic acid which has biological rebuilding functions and coenzymes in certain metabolic processes $[12,26]$. Ascorbic acid acts as an electron donor and is able to inactivate various free radicals $[5,7]$.

Obtaining a high quality food ingredient which contains the whole range of biologically active compounds requires special attention to the extraction process. One of the peculiarities that determine the choice of extraction process is different physical state of raw material and its modification in the extraction process $[10,14]$.

Extracting biologically active compounds is the main and most time-consuming stage of raw material processing [17, 22]. The difficulties connected with studying solid-phase extraction can be explained on the one hand by the indefiniteness of solid-phase structure change during target components extraction, on the other hand by polidispersity of solid phase and selectivity of the solvent $[9,20]$.

As a rule all available extraction methods are not economical and are applied with some restrictions [40]. The combination of different approaches to the extraction process can provide a sufficient, in our opinion, effectiveness of extracting bioactive compounds. Applying electro physical methods, ultrasound in particular (US), for the intensification of extraction processes can be found forward-looking $[4,35]$.
Ultrasound assisted extraction method (Acoustic Cavitation) in which ultrasound waves are passed through the liquid media of frequency $20 \mathrm{kHz}-1 \mathrm{MHz}$, the sound waves creates a series of adiabatic compression and rarefaction cycles $[4,16]$. When, this localized pressure drops below the saturation vapor pressure of the liquid, cavities are generated [19]. There are two effects of cavitation one is physical effect through which the large shearing occurs in the liquid medium there by which cell breaking happens and leads to improvement in the mass transfer that leads to the improvement in the extraction take place $[4,9,16,22]$.

According to the recent research data US impact on the colloid substances is connected with rising pressure on the phase border of the heterogeneous system $[4,16]$. In the rarefaction phase, throughout the entire volume of liquid, in particular on the phase's boundaries in those places in which the smallest solids and gas bubbles are present, cavities are formed [30]. The French scientist demonstrated the applicability of ultrasonic wave technology in the manufacture of natural products on the basis of ecoextraction processes [22].

The aim of the present paper is to evaluate the effectiveness of extracting biologically active substances of antioxidant activity from plant raw materials on the basis of applying different extraction approaches.

\section{Materials and methods}

The choice of the experimental objects and methods is related to the purpose of the research. Two plant species - Lonicera caerulea L. and Urtica folia L. - served as the objects of the experiment.

\section{Plant materials}

Honeysuckle berries (Lonicera saerulea L.), produced by the NGO Gardens of Russia. The raw material was collected at optimum ripening stage recommended for consumption. Reconstituted extract from a mixture of direct squeezed juice and extract of pulp obtained on the basis of applying ultrasonic treatment, subjected to freeze drying.

Crushed nettle leaves (Urtica folia L.), produced by Fitofarm Ltd., Anapa, Russia. Pieces of various shape passing through the $7 \mathrm{~mm}$ sieve, of dark green colour. The smell is weak. Humidity $-14 \%$. Pharmacopoeial raw material was purchased in the pharmacy chain.

\section{Extraction procedure}

For extraction, the following devices were used: 
- UZTA-0.4 / 22-OM ultrasonic technological model. Ultrasonic processing mode: $2 \mathrm{~kW}$ with a frequency of $22 \pm 1.65 \mathrm{kHz}$, ultrasonic vibration intensity of $10 \mathrm{~kW} / \mathrm{cm}^{2}$, ultrasonic output power range of $0-400 \mathrm{~W}$.

- Ultrasonic technological model UZTA-0,63 / 22-OL (extraction). The ultrasonic treatment mode is $2 \mathrm{~kW}$ with a frequency of $22 \pm 1.65 \mathrm{kHz}$, the intensity of ultrasonic oscillations is $2-10$ $\mathrm{kW} / \mathrm{cm}^{2}$, the ultrasonic output power range is 0-630 W.

The ultrasonic vibrating system uses annular piezoelectric elements and is made of BT5 titanium alloy. Its operating principle is based on high-intensity ultrasonic waves propagating in fluid and in fluid-dispersed substances. The engineering solutions used are protected by Russian Federation patent No. 2141386 [9, 29].

Drying procedure should not induce degradation of thermolabile substances, which is why lyophilization is one of the best ways of obtaining this type of product [2]. Hence, freeze frying was carried out as these materials are temperature sensitive $[42,43]$.

Honeysuckle berries (Lonicera saerulea L.) dried from juices and extracts were carried out by means of a freeze-drying apparatus "Ineye-6" under the following conditions: temperature $-50 \pm 5{ }^{\circ} \mathrm{C}$, pressure no more than $6 \mathrm{~Pa}$. A lowtemperature chamber was used to freeze the juices and extracts.

Our technological scheme included the following operations: mechanical grinding of berries to a fraction of no more than $3 \mathrm{~mm}$. For direct extraction of juice following procedure was carried out: Initially, the pulp was mixed with distilled water, the ratio of crushed raw material to water was maintained as 1: 10 ratio. Then ultrasound cavitation was used using base transducer having frequency of $22 \pm 1.65 \mathrm{kHz}$ with intensity of ultrasound of $5 \mathrm{~W} / \mathrm{cm}^{2}$. The effective power dissipated was $80 \mathrm{~W}$ in 15 minutes.

Extracts of Urtica folia L. were prepared on the water and ethanol base ( $5 \mathrm{gm}$ of dry leaves per $100 \mathrm{ml}$ of $\mathrm{H}_{2} \mathrm{O}$ or $70 \%$ water-ethanol solution). The extraction technology included ultrasound impact of various intensity $(30 \%$ or $60 \%$ of the rating) during $5 \mathrm{~min}$. We applied infusion or Soxhlet extraction method.

All extractions were carried out in triplicate.

The content of individual phenolic substances was determined by gas chromatography using an "Agilent 6850" chromatograph (USA) with a mass spectrometer.
Equipment Details: UFLC Shimadzu Corporation Pump: LC-20AD Detector: SPD-M20A Prominence Diode array detector.

HPLC Experiment Details: Isocratic flow Buffer: Acetonitrile: Water - 60:40 Flow rate: $0.6 \mathrm{ml} / \mathrm{min}$ Oven temperature: $30^{\circ} \mathrm{C}$ Sample Injection Volume: 5 ul Run time: $20 \mathrm{~min}$.

Sample Preparation: Weigh 2 gm of dried extract and dissolve in $5 \mathrm{ml} \mathrm{D}$. water. Sonicate for $5 \mathrm{~min}$. Then the sample was filtered with $0.22 \mathrm{u}$ PVDF Syringe filters.

Antioxidant activity was determined by coulometric detection with the use of the apparatus "Expert 006 antioxidant". The coulometric detection method of defining the total antioxidant activity is based on the interaction of water extracts of the product with electro generated bromine compounds.

Calculations and graphical interpretation of model implementation results were carried out using visual programming in the MICROSOFT Office environment, Word XP, Excel XP for Windows XP. Statistical processing of the experiment results was carried out by the Student method. The degree of reliability of the experimental data was estimated using mathematical statistics methods using modern software tools MICROSOFT Office, MatCad. Experimental studies were carried out in three to five replicates for each of the variants of the experiment and control with a confidence probability of 0.95 .

\section{Results and discussion}

The constituent parts of plant raw materials have different antioxidant properties, and as shown by the results of many studies, a significant part of substances with a pronounced antioxidant effect is contained in the squeezes and pulp of plants $[11,13]$. For this reason, it is necessary to search for special technologies that make it possible to intensify the process of extracting BAS from vegetable raw materials, as well as allow maximum preservation of BAS for further use in the production of healthy foods [31, 34, 37, 39].

The study of the biochemical composition aimed at establishing the list of biologically active substances (BAS) which are the most significant in the formation of antioxidant properties, as well as their quantitative distribution of the components Lonicera saerulea L. and Urtica folia $L$.

Honeysuckle berries (Lonicera saerulea L.) are native to northeastern Russia, China, Japan and Canada. In Russia it is the only cultivated 


\section{Спортивное питание}

variety. Recently honeysuckle berries have taken leading places as not only BAS source, but also as an effective medicine for prevention and cure from various diseases as well as for restoring body functions at various disorders.

The main substances which determine the above-mentioned properties are: Epigallocatechin gallate (EGCG), Apigenin and Luteolin. Their characteristics are given in Table 1. It is proved that each of these bioactive substances independently or altogether can serve as a drug-free substance adaptogen for cancer prevention, problems connected with oxidative stress and for restoration from high psychological and physiological burden.

The content of the main groups of biolo- gically active substances was determined in the berries of frozen crushed, direct pressed and squeezed milk. The characteristic types of chromatograms are shown in Fig. 1.

Description of the Plant Cover analysis

From the Chromatogram we observe 3 peaks at $4.195,4.573$ and 5.080 which corresponds to the compounds Apigenin, Luteolin and EGCG. This assumption is based on the Mol. mass of the compounds.

\section{Description of the Plant Juice analysis}

From the Chromatogram we observe 4 peaks at $4.317,4.523,4.655$ and 5.052. From these peaks we can deduce that 3 compounds Apigenin, Luteolin and EGCG were present. Apart from that

Characteristics of bioactive compounds identified in honeysuckle extracts $[3,25,41]$

Table 1

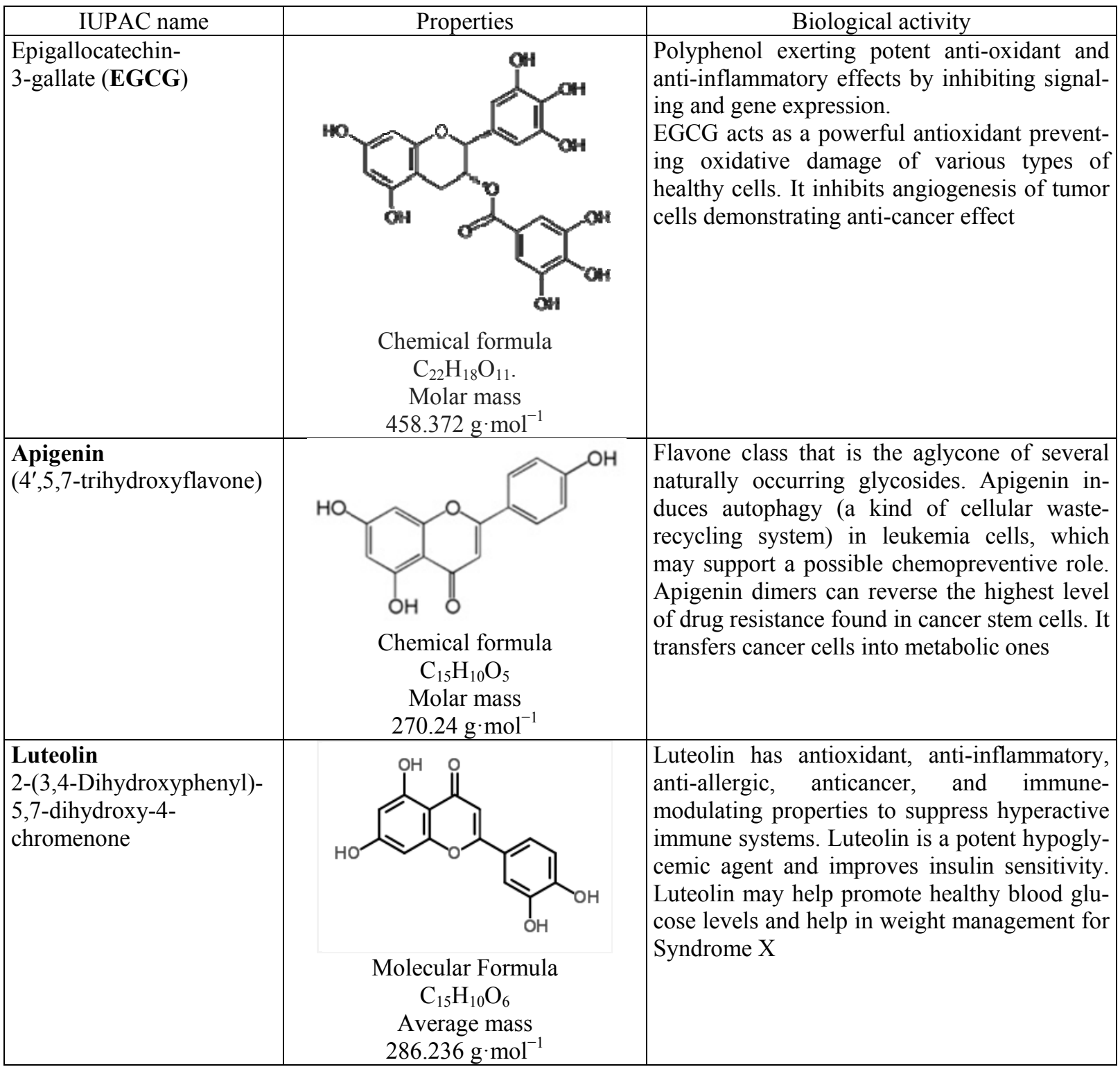


one more peak is observed at 4.655 which was not observed in the Plant cover sample chromatogram. At this point that particular peak is unknown. The final results are presented in Table 2.

The extracts of berries contain substances present in the original plant raw materials in rela- tively similar quantities. This is confirmed by the results of the comparative analysis.

In addition, the proposed method for obtaining the extract based on the application of ultrasound and freeze-drying ensures the disinfection of the product without using a thermal

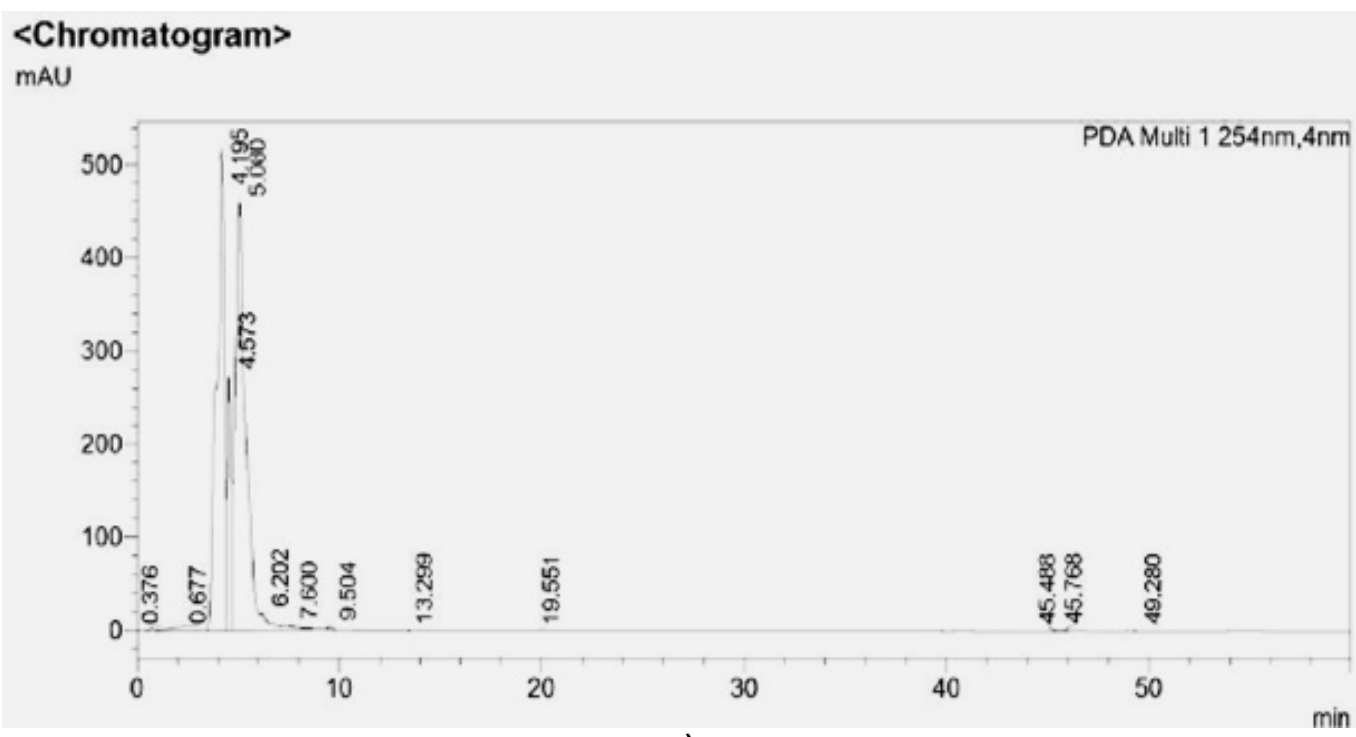

a)

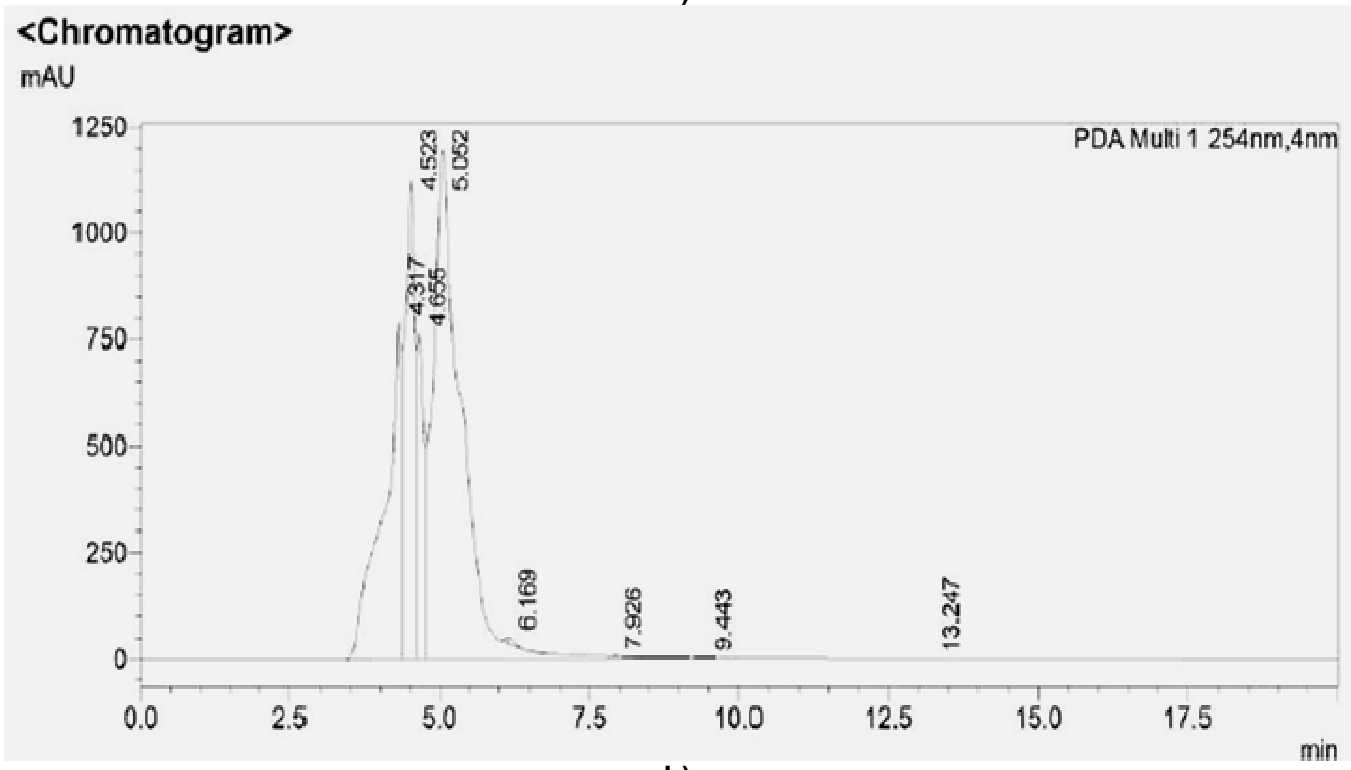

b)

Fig. 1. Typical type of chromatogram of honeysuckle products, detection of $254 \mathrm{~nm}$ (a-juice, b-extract)

Table 2

Content of the main groups of biologically active substances determining the antioxidant properties in the experimental objects

\begin{tabular}{|l|c|c|c|}
\hline \multicolumn{1}{|c|}{ Name of the parameter } & \multicolumn{3}{c|}{ Experimental objects } \\
\cline { 2 - 4 } & berries & juice & extraction \\
\hline Total phenolic content equivalent to chlorogenic acid, \% & $0,234 \pm 0,01$ & $0,318 \pm 0,02$ & $0,173 \pm 0,01$ \\
\hline $\begin{array}{l}\text { Total content of flavonoid compounds equivalent } \\
\text { to quercetin, \% }\end{array}$ & $1,533 \pm 0,01$ & $1,253 \pm 0,01$ & $1,240 \pm 0,02$ \\
\hline Total content of anthocyanins, \% & $1,86 \pm 0,02$ & $0,93 \pm 0,01$ & $1,72 \pm 0,01$ \\
\hline
\end{tabular}




\section{Спортивное питание}

attack, which is destructive for most biologically active substances.

It is convenient to interpret the results of chromatographic analysis of multicomponent plant systems from the viewpoint of hydrophilic, hydrophobic properties of sorbates [32]. Thus, in reversed-phase HPLC, the phenolic compounds will be retained depending on the degree of hydroxylation: the higher it is, the less the retention time is. Therefore, simple phenols, anthocyanidins, phenylpropanoids, lignans, etc., as well as their glycosides with a high degree of hydroxylation on the aglycone elute from the column first $[36,41]$. This character of retention is consistent with the concept of the solvophobic mechanism, when lipophilic compounds are displaced from the free volume of the mobile phase to the hydrophobic surface of the octadecyl silica gel [27, 28].

The given chromatograms as well as the quantitative connection of analyzed components show that eluting components mainly up to $8 \mathrm{mi}$ nutes are the analytes demonstrating their antioxidant properties. On the other hand, the components undergoing isocratic elution in the range of 20-50 minutes show predominant neuroprotective and psychostimulating properties. The content of the components of the first group quantitatively prevails both in the samples of juice and the extract of the fruit slurry (Fig. 1).

Scientific studies of the biological effects of honeysuckle berries extracts show that the presence of anthocyanins, polyphenols and other biologically active compounds in them determines their ability to possess antibacterial, antioxidant, anti-inflammatory and carcinoprotective effects.

Thus, JitkaVostalova et al's experimental study [38] demonstrates an inhibitory effect of the honeysuckle extract on microsomal peroxidation in rat liver and reduced oxidation of low density lipoproteins. Oral administration of cranberry extract to rats resulted in a decrease in proinflammatory cytokines (TNF- $\alpha$, IL-1 $\beta$, IL-6) in the blood serum, and a significant decrease in the synthesis of cyclooxygenase-2 (COX-2) in the spleen. The level of antioxidant enzymes in blood plasma, on the contrary, significantly increased $[39,40]$. The anti-inflammatory effect of the honeysuckle extract was shown in a study by Jinetal, 2006 in rats with induced bacterial lipopolysaccharide yeave [38]. Other studies have proved that honeysuckle extract has a protective effect against UVA and UVB radiation, and also inhibits melanogenesis [39, 40].

Based on our studies, we validated the scheme for the production of a dry water-soluble extract, which includes: grinding berries, separating the juice of direct pressing; mixing cake with distilled water in a ratio of $1: 10$, extraction using ultrasound in a mode of $22 \pm 1.65 \mathrm{kHz}$ with an ultrasound intensity of no more than $5 \mathrm{~W} / \mathrm{cm}^{2}$ with an effect of $80 \mathrm{~W}$ for $15 \mathrm{~min}$, filtering the extract, freezing the juice and extract, their lyophilic drying at a temperature of $-50 \pm 5{ }^{\circ} \mathrm{C}$ at a pressure of $1 \pm 3 \mathrm{~Pa}$ and co-milling into powder.

The next step was to evaluate the antioxidant activity of the already restored berry extracts. The reduction process took place at room temperature, by mechanically mixing the dry extract and the prepared water in the ratio of $1 \div 4$ (5), the mass fraction of dry substances to the finished beverage was not less than $15 \%$. The total antioxidant activity (AOA) of the reconstituted aqueous extract (coulometric method) was $116 \pm$ $\pm 14 \mathrm{mg}$ ascorbic acid $/ \mathrm{ml}$. The characteristic

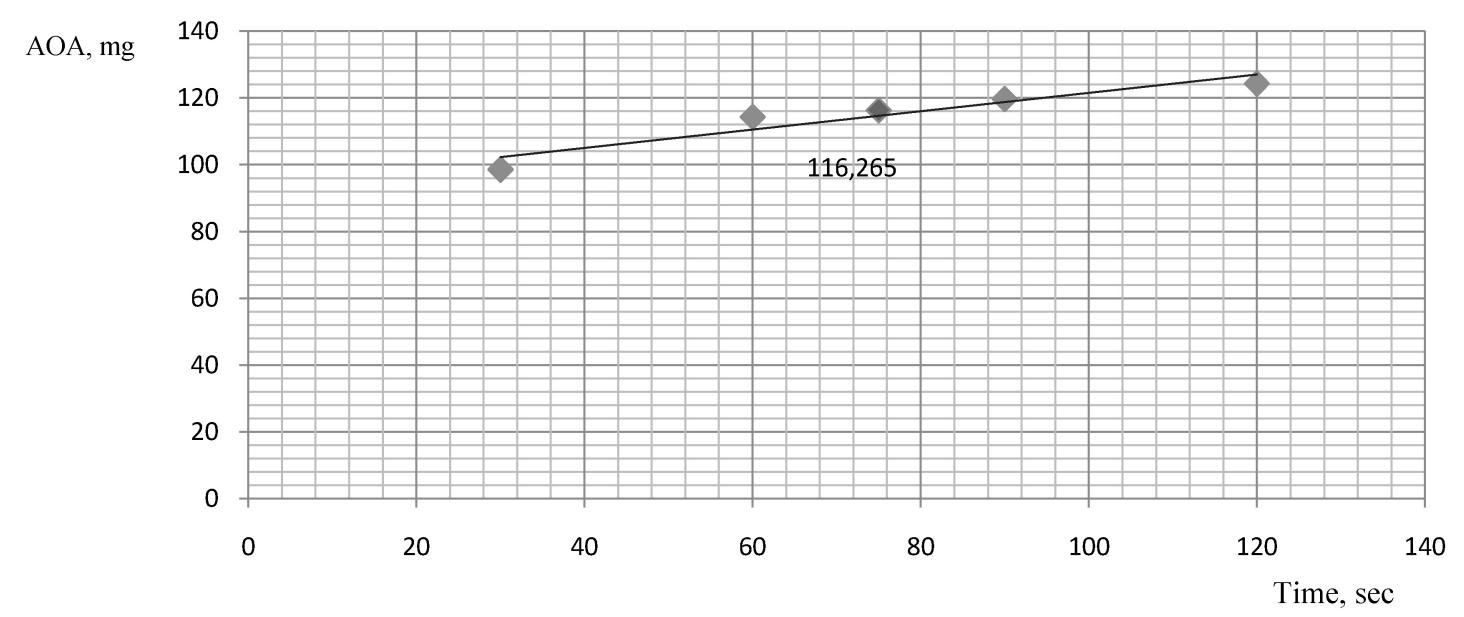

Fig. 2. AOA of the reconstituted extract of honeysuckle, $\mathrm{mg}$ ascorbic acid/ml 
shape of the curve for the determination of AOA by the coulometric method is shown in Fig. 2.

Thus, the results of the conducted studies showed the efficiency of the intensification of the extraction process by introducing ultrasound. The proposed technology for the production of dry water-soluble extracts, in our opinion, will make it possible to improve the consumer characteristics of beverages and their physiological value, as well as expand the scope of extracts for the production of healthy foods. Based on the results of the research, we defined the technological parameters for obtaining a dry extract using ultrasound and freeze-drying in order to maximize the preservation of the biologically active substances of plant raw materials (up to $92-85 \%$ ).

Nettle leaves Urtica folia $L$. Diagnostic description and chemical composition of common nettle are presented in Table 3 below. The con- tent of bioactive compounds varies depending on the vegetative part, however, the prevailing compounds determining antioxidant activity are found in the leaves. The predominant group determining antioxidant activity is falovoinds and vitamin $\mathrm{C}$.

For obtaining extracts we used dried leaves of Urtica folia L. The experiment was based on the following extraction factors: extraction agents $B A S$ ( $70 \%$ water and water-ethanol solution); different ultrasonic treatment $(120 \mathrm{~W}-30 \%$ of the rating; $240 \mathrm{~W}-60 \%$ of the rating) of an extraction agent during $5 \mathrm{~min}$; extraction method (infusion and distillation).

The obtained extracts were evaluated according to a wide range of parameters determining the effect of extraction method on the transfer of biologically active compounds into the extraction agent. The extracts were analysed on the base of

Description of diagnostic features of Urtica folia $L$ vegetative parts and their chemical composition

Table 3

\begin{tabular}{|l|l|c|c|c|c|}
\hline \multirow{2}{*}{$\begin{array}{c}\text { Vegetative } \\
\text { parts }\end{array}$} & \multicolumn{1}{|c|}{$\begin{array}{c}\text { Characteristics } \\
\text { of diagnostic features }\end{array}$} & $\begin{array}{c}\text { Vitamin C, } \\
\mathrm{mg} \%\end{array}$ & $\begin{array}{c}\text { Tanning } \\
\text { substances, \% }\end{array}$ & $\begin{array}{c}\text { Flavonoids, } \\
\mathrm{mg} \%\end{array}$ & $\begin{array}{c}\text { Cellulose, \% } \\
\text { a.c.c. }\end{array}$ \\
\hline Inflorescence & Axillary, spicate & 2,68 & 0,53 & 4,60 & 24,20 \\
\hline Leaves & Egg-shaped, with serrated edges & 3,12 & 0,22 & 4,48 & 11,40 \\
\hline Stem & Ascending, 50-150 cm high & 2,68 & 0,53 & 4,60 & 34,90 \\
\hline
\end{tabular}

Table 4

Characteristics of assumed conditional codes of samples with ultrasonic treatment parameters

\begin{tabular}{|c|c|c|c|}
\hline \multirow{2}{*}{$\begin{array}{c}\text { Conditional Code } \\
\text { (US Mode) }\end{array}$} & \multicolumn{3}{|c|}{ Ultrasound Treatment Modes } \\
\hline & $\mathrm{t}, \mathrm{min}$ & \multicolumn{2}{|c|}{ Ultrasound Power, $\%$} \\
\hline \multicolumn{4}{|c|}{ Water extract } \\
\hline Control & \multicolumn{3}{|c|}{ No Treatment } \\
\hline Sample 1 & 5 & 30 & \\
\hline Sample 2 & 5 & & 60 \\
\hline Sample 3 (distillation) & \multicolumn{3}{|c|}{ No Treatment } \\
\hline \multicolumn{4}{|c|}{ Ethanol extract } \\
\hline Sample 4 (distillation) & \multicolumn{3}{|c|}{ No Treatment } \\
\hline
\end{tabular}

* - conditions of ultrasonic treatment, taking into account the variations in power and time of treatment ( $120 \mathrm{~W}-30 \%$ of the rating, $240 \mathrm{~W}-60 \%$ of the rating).

Results of studying AOA parameters of Urtica folia L. extracts in relation to extracted BAS

Table 5

\begin{tabular}{|l|c|c|c|c|c|}
\hline \multirow{2}{*}{ Parameter } & \multicolumn{5}{|c|}{ Name of the sample } \\
\cline { 2 - 6 } & Control sample & Sample 1 & Sample 2 & Sample 3 & Sample 4 \\
\hline AOA, mg/ml & 2,0773 & $\mathbf{2 , 4 0 4 3}$ & 1,9748 & 1,9629 & $\mathbf{2 , 5 2 0 9}$ \\
\hline $\begin{array}{l}\text { Mass fraction of dried } \\
\text { substances (DS), \% }\end{array}$ & 1,2 & 1,1 & 1,2 & 1,2 & $\mathbf{1 9 , 2}$ \\
\hline $\begin{array}{l}\text { Content of extractive } \\
\text { substances (ES), \% }\end{array}$ & 66,66 & 60,90 & $\mathbf{6 7 , 2 9}$ & $\mathbf{6 9 , 0 9}$ & 32,38 \\
\hline $\begin{array}{l}\text { Content of tanning } \\
\text { substances (TS), \% }\end{array}$ & 0,018 & 0,020 & 0,020 & $\mathbf{0 , 0 2 5}$ & 0,016 \\
\hline Content of vitamin C, $\mathrm{mg} \%$ & 9,2 & 9,8 & 6,4 & 12,8 & $\mathbf{2 5 , 6}$ \\
\hline
\end{tabular}




\section{Спортивное питание}

physical and chemical parameters, content of vitamins, tanning and extractive substances, AOA.

The greatest antioxidant activity in relation to the control sample refers to the extract sample Urtica folia L. (2,4043 $\mathrm{mg} / \mathrm{ml})$, obtained by using $120 \mathrm{~W}$ ultrasonic treatment and the extract sample based on the water-ethanol extraction agent without ultrasonic treatment $(2,5209 \mathrm{mg} / \mathrm{ml})$.

Comparing the obtained data we can arrange them in the descending order concerning the number of components in the extracts:

tion from high psychological and physiological burden.

\section{Conclusion}

Dry extract of Lonicera caerulea $L$ by means of ultrasound and freeze-drying for preserving the maximum bioactive compounds of raw material (up to $92-85 \%$ ). From the study, it is found that for the extraction of antioxidants ultrasound plays very important role. The greatest antioxidant activity in relation to the control sample refers to the extract sample Urtica folia L. $(2,4043 \pm$

AOA sample $4>$ sample $1>$ control sample $>$ sample $2>$ sample 3

Vit C sample $4>$ sample $3>$ sample $1>$ control sample $>$ sample 2

DS sample $4>$ sample $3>$ control sample $>$ sample $2>$ sample 1

ES $\quad$ sample $3>$ sample $2>$ control sample $>$ sample $1>$ sample 4

TS $\quad$ sample $3>$ sample $1>$ sample $2>$ control sample $>$ sample 4

It is proved that ultrasonic treatment improves the kinetics of extraction and output of biologically active compounds from the substrate. The extraction technology excludes the stage of infusion which reduces energy intensity. These effects are determined by the implosion of bubbles generated by cavitation effect. The temperature and pressure created during implosion destroy the cell membrane of plant raw material and its content is emitted in the environment of the extraction agent. Ultrasound treatment of 120 $\mathrm{W}$ during $5 \mathrm{~min}$ is effective for preserving antioxidants (AOA 2,4043 $\pm 0,084 \mathrm{mg} / \mathrm{ml}$ whereas the control sample is $2,0773 \pm 0,06 \mathrm{mg} / \mathrm{ml})$. Increasing intensity up to $240 \mathrm{~W}$ provides significant rising of the parameter "Content of extractive substance" $-67,29 \pm 1,2 \%$ whereas the control sample has $66,66 \pm 0,9 \%$.

Thus, studying the suggested approaches for extracting biologically active substances from the point of their applicability in food ingredients industry we must take into account that using ethanol solutions as extraction agents is connected with additional impact on biologically active substances in the stripping process of ethanol fraction. The application of freeze-drying for fractionating plant raw material provides high effectiveness of preserving the whole range of active substances including Epigallocatechin gallate (EGCG), Apigenin, Luteolin. Besides, effective extracting of bioactive substances from medicinal plants Lonicera caerulea $L$. and Urtica folia $L$ permits obtaining new food ingredients. The identified bioactive compounds of Lonicera caerulea $L$ can serve as a drug-free substance adaptogen for cancer prevention, problems connected with oxidative stress and for restora- $\pm 0,84 \mathrm{mg} / \mathrm{mL}$ ), obtained by using $120 \mathrm{~W}$ ultrasonic treatment. It is also important to conclude that the application of ultrasound and freeze-drying ensures the disinfection of the product without using a thermal attack, which is destructive for most biologically active substances.

This article was written with support from the Government of the RF (Resolution No. 211 of 16.03.2013), Agreement No. 02.A03.21.00 11 and subsidies for the fulfillment of a fundamental part of a state order, project No. 40.8095.2017/BCh, No. 19.8259.2017/BCh. The work was supported by Act 211 Government of the Russian Federation, contract No. 02.A03.21.0011.

\section{References}

1. Afanas'ev I.B., Dorozhko A.I., Brodskii A.V., Kostyuk V.A., Potapovitch A.I. Chelating and Free Scavenging Mechanisms of Inhibitory Action of Rutin and Quercetin in lipid Peroxidation. ZBiochem. Pharmacol, 1989, vol. 38, pp. 1763-1769.

2. Amarowicz R., Troszyńska A., Pegg R.B. Antioxidative and Radical Scavenging Effects of Phenolics from Vicia Sativum. Fitoterapia, 2008, vol. 79, pp. 121-122. DOI: 10.1016/j.fitote.2007. 07.018

3. Andriy G. Development and Validation of a RP-HPLC Method for the Simultaneous Estimation of Luteolin and Apigenin in Herb of Achillea Millefolium. Pharma Innovation, 2013, no. 2, pp. 7-14. DOI: 10.1016/j.jtusci.2016.10.004

4. Ashokkumar M., Lee J., Zisu B., Bhaskarcharya R., Palmer M. \& Kentish S. Hot Topic: Sonication Increases the Heat Stability of Whey Proteins. Journal of Dairy Science, 2009, no. 92, pp. 5353-5356. DOI: 10.3168/jds.2009-2561

5. Borisova M.S. Lechenie klyukvoy, brusnikoy, chernikoy [Treatment of Cranberries, Lingonberries, Blueberries]. St. Petersburg, Letters, 2003. $58 \mathrm{p}$.

6. Brown J.E., Khodr H., Hider R.C., Rice- 
Evans C.A.J. Structural Dependence of Flavonoid Interactions with $\mathrm{Cu} 2+$ Ions: Implications for their Antioxidant Properties. Biochem, 1998, vol. 330, pp. 1173-1178.

7. Dadali V.A. Makarov, V.G. Biologically Active Substances of Medicinal Plants as a Factor of Detoxification. The Supply Issues, 2003, no. 5, pp. 49-55.

8. Elim, H.-J., Chen F., Wang X., Chung H.Y., Jin Z. Evaluation of Antioxidant Activity of Vetiver (Vetiveria Zizanioides L.) Oil and Identification of its Antioxidant Constituents. J. Agric. Food Chemistry, 2005, vol. 53, pp. 7691-7695.

9. Fatkullin R., Popova N., Kalinina I., Botvinnikova V. Application of Ultrasonic Waves for the Improvement of Particle Dispersion in Drinks. Agronomy Research, 2017, no. 15, pp. 1295-1303.

10. Golovina, E.Yu., Branova T.A. [The Content of Antioxidants in Leaves of Some Legumes of the City of Kaliningrad]. Bioantioxidant: $A b$ stracts of $8^{\text {th }}$ International Conference. Moscow, 2010, pp. 58-59. (in Russ.)

11. Golub O.V., Chakrya G.P., Motovilov D.C. [Formation of the Quality Characteristics of Fermented Beverage Based on Honey and Plant Materials]. Beer and Drinks, 2015, no. 5, pp. 26-30. (in Russ.)

12. Materialy 6-y Mezhdunarodnoy konferentsii "Fitoterapiya, biologicheski aktivnye veshchestva estestvennogo proiskhozhdeniya v sovremennoy meditsine" [International Scientific Conference "Herbal Medicine, Biologically Active Substances of Natural Origin"], 2004, pp. 260-268. (in Russ.)

13. Katalinic V., Milos M., Kulisic T., Jukic M. Screening of 70 Medicinal Plant Extracts for Antioxidant Capacity and Total Phenols. Food Chemistry, 2006, vol. 94, pp. 550-557. DOI: 10.1016/j.foodchem.2004.12.004

14. Kiseleva T.F., Zaitsev S.I. [Identification of Prerequisites for Complex Processing of Fruit and Berry Raw Materials of the Siberian Region]. Technics and Technology of Food Production, 2009, no 3, pp. 7-11. (in Russ.)

15. Korulkin D.Yu., Abilov Zh.A., Muzychkina R.A., Tolstikov G.A. Prirodnye flavonoidy [Natural Flavonoid]. Novosibirsk, Theo, 2007. $232 \mathrm{p}$.

16. Krasulya O., Shestakov S., Bogush V., Potoroko I., Cherepanov P. and Krasulya B. Applications of Sonochemistry in Russian Food Processing Industry. Ultrasonics Sonochemistry, 2014, no. 21, pp. 2112-2116. DOI: 10.1016/j.ultsonch.2014.03.015
17. Masaki H., Sakaki S., Atsumi T., Sakurai H. Active-Oxygen Scavenging Activity of Plant Extracts. Biol. Pharm. Bul., 1995, vol. 18, pp. 162-166.

18. Melidou M. Riganakos K., Galaris D. Protection Against Nuclear DNA Damage Offered by Flavonoids in Cells Exposed to Hydrogen Peroxide: the Role of Iron Chelation. Free Radic. Biol. Med, 2005, vol. 39, pp. 1591-1600. DOI: 10.1016/j.freeradbiomed.2005.08.009

19. Naumenko N.V., Kalinina I.V. Sonochemistry Effects Influence on the Adjustments of Raw Materials and Finished Goods Properties in Food Production. Materials Science Forum, 2016, vol. 870, pp. 691-696.

20. Okubo T.N., Ishinara N., Oura A., Serit M., Kim M., Yamamoto T., Mitsuoka T. In Vivo Effects of Tea Polyphenol Intake on Human Intestinal Microflora and Metabolism. Biosci. Biotechnol. Biochem, 1992, vol. 56, pp. 588-591.

21. Pietta P.-G. Flavonoids as Antioxidants. J. Nat. Prod, 2000, vol. 63, pp. 1035-1042.

22. Potoroko I.Y., Kretova Y.I., Kalinina I.V. [Practical Aspects of the Use of Resource Efficient Technologies in Food Production as a Factor in the Quality of Finished Goods]. Goods manager of Food Products, 2014, no. 10, pp. 8-13. (in Russ.)

23. Rice-Evans C.A. Miller N.M., Paganda G. Structure Antioxidant Activity Relationships of Flavonoids and Phenolic Acids. Free Radic. Biol. Med, 1996, vol. 20, pp. 933-956. DOI: 10.1016/0891-5849(95)02227-9

24. Rice-Evans C.A., Miller N.J., Bolwell P.G., Bramley P.M., Pridham J.B. The Relative Antioxidant Activities of Plant-Derived Polyphenolic Flavonoids. Free Radic. Res, 1995, vol. 22, pp. 375-383.

25. Shanmuga Sundaram Rajagopal, Babitha K Vazhayil, Liz Varghese, Mahadevan Nanjaian Development, Validation of RP-HPLC Method for Simultaneous Determination of Apigenin and Luteolin in Ethanol Extract of Clerodendrum serratum (Linn.) Leaves. Asian Journal of Applied Sciences, 2017, no. 05 (01), pp. 52-60. DOI: 10.1016/j.jpha.2013.09.008

26. Shatilov A.V., Bogdanova O.G., Korobov A.V. [The role of Antioxidants in a Human Body: Norm and Pathology]. Veterinary Pathology, 2007, no. 2, pp. 207-211. (in Russ.)

27. Shcherbakov D.L., Emel'yanov V.V., [Meshchaninov V.N. The Influence of Adrenaline on Lipid Peroxidation in Myelokaryocytes of Adult and Old Rats in Vitro]. Vestnik uralskoy 


\section{Спортивное питание}

meditsinskoy akademicheskoy nauki, 2013, no. 4, pp. 102-105. (in Russ.)

28. Shcherbakov D.L., Emel'yanov V.V., Meshchaninov V.N. [Triptofan and Nicotinic Acid as Antioxidants in Different Age Rats Brain at the Immobilization Stress]. Uspekhi gerontologii, 2014, no. 27 (4), pp. 730-736. (in Russ.)

29. Shestakov S. et al. A New Look at Cavitation and the Applications of Its Liquid-Phase Effects in the Processing of Food and Fuel. Applied Physics Research, 2012, vol. 4, pp. 19-29.

30. Shestakov S. Babak V. Mathematical Model of the Spatial Distributing of Density of Erosive Power of Multibubble Cavitation. Applied Physics Research, 2012, no. 4, pp. 64-77.

31. Silva M.M., Santos M.R., Caroco G., Rocha R., Justino G., Mira L. Structure-Antioxidant Activity Relationships of Flavonoids: a Reexamination. Free Radic. Res, 2002, vol. 36, pp. 1219-1227.

32. Skerget, M., Z. Knez, M. Habulin, Solubility of B-carotene and Oleic Acid in Supercritical Carbon Dioxide and Data Correlation by a Density Based Model. Fluid Phase Equil, 1995 , no. 109 , pp. 131-138. DOI: 10.1016/03783812(95)02717-S

33. Spencer J.P.E., Chowrimootoo G., Choudhury R., Debnam E.S., Srai S.K., RiceEvans C. The Small Intestine Can Both Absorb and Glucuronidate Luminal Flavonoids. FEBS Lett, 1999, vol. 458, pp. 224-230.

34. Spencer, J.P.E. Mohsen M.M.A.E., Rice-Evans C. Cellular Uptake and Metabolism of Flavonoids and Their Metabolites: Implications for Their Bioactivity. Arch. Biochem. Biophys, 2004, vol. 423, pp. 148-161.

35. Tian-yang Wang, Qing Li, Kai-shun Bi. Bioactive Flavonoids in Medicinal Plants: Structure, Activity and Biological Fate. Asian Journal of Pharmaceutical Sciences. Available online 15 August 2017. DOI: 10.1016/j.ajps.2017.08.004

36. Usov A.I., Smirnova G.P., Klochkova N.G. [Polysaccharide Composition of Certain Brown Algae of Kamchatka]. Bioorgan. khimiya
[Bioorganic Chemistry], 2001, vol. 27, no. 6, pp. 444-448. (in Russ.)

37. Vitaly Roginsky. Chain-Breaking Antioxidant Activity of Natural Polyphenols as Determined During the Chain Oxidation of Methyl Linoleate in Triton X-100 Micelles. Archives of Biochemistry and Biophysics, 2003, no. 15, pp. 261-270. DOI: 10.1016/S0003-9861(03)00143-7

38. Vostalova J., Galandakova A., Palikova I., Ulrichova J., Dolezal D., Lichnovska R., Vrbkova J., Rajnochova A.S. Lonicera Caerulea Fruits Reduce UVA-Induced Damage in Hairless Mice. Journal of Photochemistry and Photobiology B: Biology, 2013, no. 5, pp. 1-11. DOI: 10.1016/j.jphotobiol.2013.07.024

39. Wu L.-C., Hsu H.-W., Chen Y.-C., Chin C.-C., Lin Y.-I., Ho J.A. Antioxidant and Antiproliferative Activities of Red Pitaya. Food Chem, 2006, vol. 95. pp. 319-327.

40. Wu, Jia-Jiuan, Jung-Chuan Lin, ChihHung Wang et al. Extraction of Antioxidative Compounds from Wine Lees Using Supercritical Fluids and Associated Anti-Tyrosinase Activity. $J S F, 2009$, no. 50, pp. 33-41.

41. Xiao, Q.C., Jian, B.X. RP-HPLC-DAD Determination of Flavonoids: Separation of Quercetin, Apigenin and Luteolin in Marchantia Convolute. Iranian Journal of Pharmaceutical Research, 2009, no. 54, 175-181. DOI: 10.1016/j.indcrop.2012.04.043

42. Zavorohina N.V. [Simulation of Drinks Directed Social Activity Taking Into Account Specifics of the Region]. Beer and Drinks, 2013, no. 6, pp. 8-12. (in Russ.)

43. Zavorohina, N.V., Chugunova O.V., Fozilova V.V. [Tea Drinks Antioxidant Orientation on the Basis of Epilobium Angustifolium]. Beer and Drinks, 2013, no. 1, pp. 28-31. (in Russ.)

44. Zheng M., Wang X., Templeton L.J., Smulski D.R., LaRossa R.A., Storz G. DNA Microarray-Mediated Transcriptional Profiling of the Escherichia Coli Response to Hydrogen Peroxide. Journal of Bacteriology, 2001, vol. 183, pp. 45624570. DOI: 10.1128/JB.183.15.4562-4570.2001 


\title{
ВОЗМОЖНОСТИ РЕГУЛИРОВАНИЯ АНТИОКСИДАНТНОЙ АКТИВНОСТИ ЭКСТРАКТОВ ЛЕКАРСТВЕННЫХ РАСТЕНИЙ
}

\author{
И.Ю. Потороко ${ }^{1}$, И.В. Калинина ${ }^{1}$, Н.В. Науменко ${ }^{1}$, Р.И. Фаткуллин ${ }^{1}$, \\ Ш. Шаик ${ }^{2}$ Ш. Сонавейн ${ }^{2}$, Д. Иванова ${ }^{3}$, Й. Киселова-Канева ${ }^{3}$, О.А. Толстых \\ А.В. Паймулина 1 \\ ${ }^{1}$ Южно-Уральский государственный университет, г. Челябинск, Россия, \\ ${ }^{2}$ Национальный технологический институт, г. Варангал, Индия, \\ ${ }^{3}$ Медицинский университет им. профр. доктора Параскев-Стоянова г. Варна, Болгария
}

Цель работы. Целью настоящей работы является оценка эффективности извлечения биологически активных веществ антиоксидантного действия из растительного сырья на основе применения различных методов экстракции. Материалы и методы. Проведены химические исследования экстрактов биологически активных веществ из Lonicera caerulea $L$. и Urtica folia L. По их миграционным параметрам на основе разделения фракций (плоды жимолости) и изменения условий экстрагирования (высушенные листья крапивы). Для сохранения биологически активных веществ жимолостных фракций применялась лиофилизация сырья (использовался аппарат «Иней-6», сушка протекала при следующих условиях: температура $-50 \pm 5{ }^{\circ} \mathrm{C}$, давление не более 6 Па). Эксперимент включал широкий спектр химических параметров - антиоксидантная активность (АОА), массовая доля экстрактивных веществ, фенольных соединений, антоцианов и витаминов. Использовался метод ВЭЖХ с применением Shimadzu LC-20AD. Детектор: SPD-M20А. Для определения биологически активных веществ была использована диодная матрица. Результаты и обсуждение. В статье исследовано влияние различных подходов к извлечению биоактивных соединений из Lonicera caerulea L. и Urtica folia L. Применение ультразвука (У3) с частотой $22 \pm 0,6$ кГц повышает эффективность процесса экстракции, что позволяет вести экстракцию при низкой температуре $\left(60 \pm 2{ }^{\circ} \mathrm{C}\right)$ без использования химических реагентов. В статье представлены результаты экстракции водным и водно-спиртовым растворами из различных фракций плодов жимолости и высушенных листьев крапивы. Также представлены результаты анализа антиоксидантной активности данных экстрактов. Наибольшей антиоксидантной активностью отличались водный экстракт Urtica folia L., полученный с применением У3 мощностью 120 Вт $(2,4043 \pm 0,084$ мг/мл), и водно-спиртовой экстракт Urtica folia L. без У3 (2,5209 \pm 0,032 мг/мл). Определены технологические параметры получения сухого экстракта Lonicera caerulea L. с помощью ультразвука и сублимационной сушки с максимальным сохранением биологически активных компонентов сырья (до 92-85 \%). Вывод. Результаты эксперимента показали, что ультразвуковая экстракция улучшает кинетику экстракции и выход биоактивных соединений из субстрата. Технология экстракции исключает этап инфузии, что снижает энергоемкость процесса.

Ключевые слова: лекарственные растения, экстракция, биологически активные вещества, антиоксидантная активность, ультразвук.

\section{Лumepamypa}

1. Afanas'ev, I.B. Chelating and free scavenging mechanisms of inhibitory action of rutin and quercetin in lipid peroxidation / I.B. Afanas'ev, A.I. Dorozhko, A.V. Brodskii, V.A. Kostyuk // ZBiochem. Pharmacol. - 1989. - Vol. 38. - P. 1763-1769.

2. Amarowicz, $R$. Antioxidative and radical scavenging effects of phenolics from Vicia sativum / R. Amarowicz, A. Troszyńska, R.B. Pegg // Fitoterapia. - 2008. - Vol. 79. - P. 121-122.

3. Andriy, G. Development and validation of a RP-HPLC method for the simultaneous estimation of luteolin and apigenin in herb of Achillea millefolium / G.Andriy // Pharma Innovation. - 2013. - No. 2. P. 7-14. 


\section{Спортивное питание}

4. Ashokkumar, M. Hot topic: Sonication increases the heat stability of whey proteins / M. Ashokkumar, J. Lee, B. Zisu, R. Bhaskarcharya // Journal of Dairy Science. - 2009. - No. 92. - P. 5353-5356.

5. Борисова, М.С. Лечение клюквой, брусникой, черникой / М.С. Борисова СПб.: Изд-во «Лиmepa», 2003. $-58 \mathrm{c}$.

6. Brown, J.E. Structural dependence of flavonoid interactions with Cu2+ ions: implications for their antioxidant properties / J.E. Brown, H. Khodr, R.C. Hider, C.A. Rice-Evans // Biochem. - 1998. Vol. 330. - P. 1173-1178.

7. Dadali, V.A. Biologically active substances of medicinal plants as a factor of detoxification V.A. Dadali, V.G. Makarov // The supply issues, 2003, No. 5. - P. 49-55.

8. Elim, H.-J. Evaluation of antioxidant activity of vetiver (Vetiveria zizanioides L.) oil and identification of its antioxidant constituents / H.-J. Elim, F. Chen, X. Wang, H.Y. Chung, Z. Jin // J. Agric. Food Chemistry. - 2005. - Vol. 53. - P. 7691-7695.

9. Fatkullin, R. Application of ultrasonic waves for the improvement of particle dispersion in drinks / R. Fatkullin, N. Popova, I. Kalinina, V. Botvinnikova // Agronomy Research. - 2017. - No. 15. P. $1295-1303$.

10. Головина, Е.Ю. Содержание антиоксидантов в листьях некоторых растений семейства бобовые г. Калининграда / Е.Ю. Головина, Т.А. Брахнова // Тезисы докладов VIII международной конференции «Биоантиоксидант». Москва, 4-6 окт. 2010 г. - М.: РУДН, 2010. - 558 c.

11. Голуб, О.В. Формирование качественных характеристик сброженного напитка на основе меда растительного сырья / О.В. Голуб, Г.П. Чекрыга, О.К. Мотовилов // Пиво и напитки. 2015. - № 5. - C. 26-30.

12. Материаль 6-й Международной конференщии «Фитотерапия, биологически активные вещества естественного происхождения в современной медицине». - Черноголовка, 2006. C. 260-268.

13. Katalinic, V. Screening of 70 medicinal plant extracts for antioxidant capacity and total phenols / V. Katalinic, M. Milos, T. Kulisic, M. Jukic // Food Chemistry. - 2006. - Vol. 94. - P. 550-557.

14. Киселева, Т.Ф. Выявление предпосылок комплексной переработки плодово-ягодного сырья сибирского региона / Т.Ф. Киселева, И.С. Зайцева, Д.Б. Пеков, Н.В. Бабий // Техника и технология пищевых производств. - 2009. - № 3. - С. 7-11.

15. Корулькин, Д.Ю. Природные флавоноиды / Д.Ю. Корулькин, Ж.А. Абилов, Р.А. Музычкина, Г.А. Толстиков. - Новосибирск: Тео, 2007. - 232 с.

16. Krasulya, O. Applications of sonochemistry in Russian food processing industry / O. Krasulya, S. Shestakov, V. Bogush, I. Potoroko // Ultrasonics Sonochemistry. - 2014. - No. 21. - P. 2112-2116.

17. Masaki, H. Active-oxygen scavenging activity of plant extracts / H. Masaki, S. Sakaki, T. Atsumi, H. Sakurai // Biol. Pharm. Bul. - 1995. - Vol. 18. - P. 162-166.

18. Melidou, M. Protection against nuclear DNA damage offered by flavonoids in cells exposed to hydrogen peroxide: the role of iron chelation / M. Melidou, K. Riganakos, D. Galaris // Free Radic. Biol. Med. - 2005. - Vol. 39. - P. 1591-1600.

19. Naumenko, N.V. Sonochemistry effects influence on the adjustments of raw materials and finished goods properties in food production / N.V. Naumenko, I.V. Kalinina // Materials Science Forum. 2016. - Vol. 870. - P. 691-696.

20. Okubo, T.N. In vivo effects of tea polyphenol intake on human intestinal microflora and metabolism / T.N. Okubo, N. Ishinara, A. Oura, M. Serit // Biosci. Biotechnol. Biochem. - 1992. - Vol. 56. P. 588-591.

21. Pietta, P.-G. Flavonoids as antioxidants / P.-G. Pietta // J. Nat. Prod. - 2000. - Vol. 63. P. $1035-1042$.

22. Потороко, И.Ю. Практические аспекты использования ресурсоэффективных технологий в пищевых производствах как фактора качества готовой продукции / И.Ю. Потороко, Ю.И. Кретова, И.В. Калинина // Товаровед продовольственных товаров. - 2014. - № 10. - C. 8-13.

23. Rice-Evans, C.A. Structure antioxidant activity relationships of flavonoids and phenolic acids / C.A. Rice-Evans, N.M. Miller, G. Paganda // Free Radic. Biol. Med. - 1996. - Vol. 20. - P. 933-956.

24. Rice-Evans, C.A. The relative antioxidant activities of plant-derived polyphenolic flavonoids / C.A. Rice-Evans, N.J. Miller, P.G. Bolwell, P.M. Bramley // Free Radic. Res. - 1995. - Vol. 22. P. 375-383. 
25. Shanmuga, S.R. Validation of RP-HPLC Method for Simultaneous Determination of Apigenin and Luteolin in Ethanol Extract of Clerodendrum serratum (Linn.) Leaves / Shanmuga Sundaram Rajagopal, Babitha K Vazhayil, Liz Varghese, Mahadevan Nanjaian Development // Asian Journal of Applied Sciences. - 2017. - No. 05 (01). - P. 52-60.

26. Шатилов, А.В. Роль антиоксидантов в организме в норме и при патологии / А.В. Шатилов, О.Г. Богданова, А.В. Коробов // Ветеринарная патология. - 2007. - № 2. - С. 207-211.

27. Щербаков, Д.Л. Особенности влияния адреналина на перекисное окисление липидов в миелокариоцитах зрелых и старых крыс in vitro / Д.Л. Щербаков, В.В. Емельянов, В.Н. Мешанинов // Вестник Урал. мед. академ. науки. - 2013. - № 4 (46). - С. 102-105.

28. Щербаков, Д.Л. Антиоксидантное действие триптофана и никотиновой кислоты в головном мозгу крыс разного возраста при иммобилизачионном стресс-воздействии / Д.Л. Щербаков, В.В. Емельянов, В.Н. Мещанинов // Успехи геронтологии. - 2014. - Т. 27. - № 4. - С. 730-736.

29. Shestakov, S. A New Look at Cavitation and the Applications of Its Liquid-Phase Effects in the Processing of Food and Fuel / S.Shestakov // Applied Physics Research. - 2012. - Vol. 4. - P. 19-29.

30. Shestakov, S. Mathematical Model of the Spatial Distributing of Density of Erosive Power of Multibubble Cavitation /S. Shestakov, V. Babak // Applied Physics Research. - 2012. - No. 4. - P. 64-77.

31. Silva, M.M. Structure-antioxidant activity relationships of flavonoids: a reexamination / M.M. Silva, M.R. Santos, G. Caroco, R. Rochal/ Free Radic. Res. - 2002. - Vol. 36- P. 1219-1227.

32. Skerget, M. Solubility of $\beta$-carotene and oleic acid in supercritical carbon dioxide and data correlation by a density based model / M. Skerget, Z. Knez, M. Habulin // Fluid Phase Equil. - 1995. No. 109. - P. 131-138.

33. Spencer, J.P.E. The small intestine can both absorb and glucuronidate luminal flavonoids / J.P.E. Spencer, G. Chowrimootoo, R. Choudhury, E.S. Debnam // FEBS Lett. - 1999. - Vol. 458. P. 224-230.

34. Spencer, J.P.E. Cellular uptake and metabolism of flavonoids and their metabolites: implications for their bioactivity / J.P.E. Spencer, M.M.A.E. Mohsen, C. Rice-Evans // Arch. Biochem. Biophys. 2004. - Vol. 423. - P. 148-161.

35. Tian-yang WangBioactive flavonoids in medicinal plants: Structure, activity and biological fate / Tian-yang Wang, Li. Qing, Bi. Kai-shun // Asian Journal of Pharmaceutical Sciences. Available online 15 August 2017.

36. Усов, А.И. Полисахариды водорослей / А.И. Усов, Г.П. Смирнова, Н.Г. Клочкова // Биоорган. химия. - 2001. - T. 27. - № 6. - C. 444-448.

37. Vitaly Roginsky. Chain-breaking antioxidant activity of natural polyphenols as determined during the chain oxidation of methyl linoleate in Triton X-100 micelles / Vitaly Roginsky // Archives of Biochemistry and Biophysics. - 2003. - No. 15. - P. 261-270.

38. Vostalova, J. Lonicera caerulea fruits reduce UVA-induced damage in hairless mice / J. Vostalova, A. Galandakova, I. Palikova, J. Ulrichova // Journal of Photochemistry and Photobiology B: Biology. - 2013. - No. 5. - P. 1-11.

39. $W u$ L.-C. Antioxidant and antiproliferative activities of red pitaya / Wu L.-C., Hsu H.-W., Chen Y.-C., Chin C.-C., Lin Y.-I., Ho J.A. // Food Chem. - 2006. - Vol. 95. - P. 319-327.

40. Wu, Jia-Jiuan Wang Extraction of antioxidative compounds from wine lees using supercritical fluids and associated anti-tyrosinase activity / Wu, Jia-Jiuan, Jung-Chuan Lin, Chih-Hung // JSF. 2009. - No. 50. - P. 33-41.

41. Xiao, Q.C. RP-HPLC-DAD determination of flavonoids: separation of quercetin, apigenin and luteolin in Marchantia convolute / Q.C.Xiao, B.X. Jian // Iranian Journal of Pharmaceutical Research. 2009. - No. 54. - P.175-181.

42. Заворохина, Н.В. Моделирование напитков сочиальной направленности с учетом спеuифики региона / Н.В. Заворохина // Пиво и напитки. - 2013. - № 6. - C. 8-12.

43. Заворохина, Н.В. Растительное сырье уральского региона для производства безалкогольных напитков / Н.В. Заворохина, М.П. Соловьева, О.В. Чугунова, Е.В. Пастушкова, В.В. Фозилова // Пиво и напитки. - 2013. - № 4. - С. 28-31.

44. Zheng, M. DNA microarray-mediated transcriptional profiling of the Escherichia coli response to hydrogen peroxide / M. Zheng, X. Wang, L.J. Templeton, D.R. Smulski // Journal of Bacteriology. - 2001. - Vol. 183. - P. 4562-4570. 


\section{Спортивное питание}

Потороко Ирина Юрьевна, доктор технических наук, профессор, заведующий кафедрой пищевых и биотехнологий, Южно-Уральский государственный университет. 454080, г. Челябинск, проспект Ленина, 76. E-mail: irina_potoroko@mail.ru, ORCID: 0000-0002-3059-8061.

Калинина Ирина Валерьевна, кандидат технических наук, доцент кафедры пищевых и биотехнологий, Южно-Уральский государственный университет. 454080, г. Челябинск, проспект Ленина, 76. ORCID: 0000-0002-6242-9870.

Науменко Наталья Владимировна, кандидат технических наук, доцент кафедры пищевых и биотехнологий, Южно-Уральский государственный университет. 454080, г. Челябинск, проспект Ленина, 76. ORCID: 0000-0002-9520-3251.

Фаткуллин Ринат Ильгидарович, кандидат технических наук, доцент кафедры пищевых и биотехнологий, Южно-Уральский государственный университет. 454080, г. Челябинск, проспект Ленина, 76. ORCID: 0000-0002-1498-0703.

Шаик Шабана, $\mathrm{PhD}$, Департамент химической инженерии, Национальный технологический институт. 506004, г. Варангал, Штат Телангана, Индия. E-mail: shabana89.chem@gmail.com, ORCID: 0000-0001-7133-5754.

Сонавайн Шириш, доктор философских наук, профессор Департамента химической инженерии, Национальный технологический институт. 506004, г. Варангал, Штат Телангана, Индия. E-mail: shirish@nitw.ac.in, ORCID: 0000-0002-3201-6731.

Иванова Диана, доктор биологических наук, профессор отдела биохимии, молекулярной медицины и нутригеномики лаборатории нутригеномики, функциональных продуктов питания и нутрицевтиков, Медицинский университет, 9002, Болгария, г. Варна, ул. Марин Дринов, д. 55. E-mail: dg_ivanova@yahoo.com, ORCID: 0000-0002-8336-2925.

Киселова-Канева Йоана, кандидат биологических наук $(\mathrm{PhD})$, доцент, начальник отдела биохимии, молекулярной медицины и нутригеномики Лаборатории нутригеномики, функциональных продуктов питания и нутрицевтиков, Медицинский университет. 9002, Болгария, г. Варна, ул. Марин Дринов, д. 55. E-mail: ykisselova@abv.bg, ORCID: 0000-0001-9692-6227.

Толстых Ольга Анатольевна, кандидат филологических наук, доцент кафедры лингвистики и перевода, Южно-Уральский государственный университет. 454080, г. Челябинск, проспект Ленина, 76. E-mail: tolga@bk.ru, ORCID: 0000-0002-3112-7026.

Паймулина Анастасия Валерьяновна, аспирант кафедры пищевых и биотехнологий, Южно-Уральский государственный университет. 454080, г. Челябинск, проспект Ленина, 76. E-mail: paimulinaav@susu.ru, ORCID: 0000-0003-4981-717X.

Поступила в редакцию 2 ноября 20172.

\section{ОБРАЗЕЦ ЦИТИРОВАНИЯ}

Possibilities of Regulating Antioxidant Activity of Medicinal Plant Extracts / I.U. Potoroko, I.V. Kalinina, N.V. Naumenk et al. // Человек. Спорт. Медицина. 2017 - T. 17 , № $4 . \quad$ - C. $77-90$. DOI: 10.14529/hsm 170409

\section{FOR CITATION}

Potoroko I.U., Kalinina I.V., Naumenko N.V., Fatkullin R.I., Shaik S., Sonawane S.H., Ivanova D., Kiselova-Kaneva Y., Tolstykh O., Paymulina A.V. Possibilities of Regulating Antioxidant Activity of Medicinal Plant Extracts. Human. Sport. Medicine, 2017, vol. 17, no. 4, pp. 77-90. DOI: 10.14529/hsm170409 